\title{
HUBUNGAN PERSEPSI SISWA TERHADAP PENERAPAN MODEL PEMBELAJARAN KOOPERATIF TIPE TUTOR SEBAYA DENGAN PRESTASI BELAJAR FISIKA
}

\author{
Effendi \\ Program Studi Pendidikan Fisika STKIP Nurul Huda Sukaraja \\ Email: effendi85mpd@gmail.com
}

\begin{abstract}
Abstrak
Pada prinsipnya pola pembelajaran yang berpusat pada guru cenderung membuat siswa menjadi pasif. Upaya yang dapat dilakukan adalah dengan pemilihan dan penerapan model pembelajaran yang tepat sehingga sesuai dengan karakteristik peserta didik dan materi pembelajaran. Model pembelajaran yang diterapkan oleh guru diasumsikan mendapatkan persepsi yang berbeda-beda dari siswa. Tujuan penelitian ini adalah untuk mengetahui hubungan antara persepsi siswa terhadap penerapan model pembelajaran kooperatif tipe tutor sebaya dengan prestasi belajar fisika pada pokok bahasan getaran dan gelombang. $\mathrm{P}$ enelitian ini merupakan penelitian kuantitatif. Proses pembelajaran dalam kelas sampel menggunakan model pembelajaran kooperatif tipe tutor sebaya. Teknik pengumpulan data dalam penelitian ini menggunakan angket dan tes, sedangkan pengujian hipotesis menggunakan uji $z$. Berdasarkan hasil dan analisis data penelitian diperoleh skor rata-rata angket persepsi yang diperoleh siswa adalah 85,27 dari skor maksimum 125, dan nilai rata-rata tes prestasi yang diperoleh siswa adalah 67,77 dari nilai maksimum 100 . Dari pengujian hipotesis diperoleh nilai $z_{\text {tabel }}=1,96$ atau $-z_{\text {tabel }}=-1,96$ pada taraf signifikansi $5 \%$, dan $z_{\text {hitung }}=5,1895$. Nilai $z_{\text {hitung }}=5,1895$ tidak terletak antara $-1,96$ dan 1,96, sehingga Ho di tolak dan $\mathrm{Ha}$ diterima. Hal ini berarti terdapat hubungan yang signifikan antara persepsi siswa terhadap penerapan model pembelajaran kooperatif tipe tutor sebaya dengan prestasi belajar fisika pada pokok bahasan getaran dan gelombang siswa kelas VIII MTs Umbul Sari tahun pembelajaran $2014 / 2015$.
\end{abstract}

\section{Kata Kunci: Persepsi, Tutor Sebaya, Prestasi Belajar}

\section{PENDAHULUAN}

Pendidikan pada dasarnya

adalah suatu proses yang membantu manusia untuk mengembangkan dirinya sehingga mampu menghadapi segala perubahan serta permasalahan dengan sikap terbuka dan kreatif. Oleh karena itu, pembaruan pendidikan 
harus selalu dilakukan untuk diungkapkan oleh Djamarah (2010: 33) memperbaiki kualitas pendidikan. yaitu faktor internal dan faktor Perbaikan kualitas pendidikan eksternal. Faktor internal meliputi diantaranya dapat ditempuh dengan minat, motivasi dan persepsi. upaya mewujudkan proses Sedangkan faktor eksternal meliputi pembelajaran yang interaktif, inspiratif, kurikulum, strategi guru mengajar, menyenangkan, menantang, dan disiplin sekolah, fasilitas belajar dan memotivasi peserta didik untuk lingkungan sekolah.

berpartisipasi aktif.

Proses pembelajaran di sekolah dipengaruhi oleh komponen-komponen pembelajaran seperti guru, siswa, tujuan pembelajaran, materi pembelajaran, metode pembelajaran dan evaluasi pembelajaran. Komponenkomponen pembelajaran tersebut bertujuan untuk mencapai pembelajaran yang baik. Selain itu, dalam melaksanakan proses pembelajaran di sekolah profesionalisme guru sangat menentukan tingkat keberhasilan siswa dalam belajar terutama dalam pencapaian prestasi belajar. Prestasi belajar merupakan hasil dari usaha seseorang untuk mengubah dirinya dengan jalan memperoleh kecakapan baru dan hasil perubahan itu diperoleh melalui latihan dan pengalaman (Hamalik, 2005: 11). Adapun faktor-faktor yang mempengaruhi prestasi belajar seperti yang
Salah satu faktor internal yang dapat mempengaruhi prestasi belajar adalah persepsi siswa. Persepsi adalah suatu proses aktifitas seseorang dalam memberikan kesan, penilaian, pendapat, merasakan, dan menginterpretasikan sesuatu berdasarkan informasi yang ditampilkan dari sumber lain (yang dipersepsi). Sedangkan bagian dari faktor eksternal yang dapat mempengaruhi prestasi belajar adalah strategi guru mengajar termasuk diantaranya adalah penggunaan model pembelajaran. Salah satu model pembelajaran yang dapat digunakan oleh guru adalah model pembelajaran kooperatif.

Pembelajaran

kooperatif merupakan suatu pendekatan pengajaran, siswa bekerja sama dalam kelompok belajar kecil untuk menyelesaikan tugas individu atau kelompok yang diberikan oleh guru. 
Salah satu tipe dari model Umbul Sari Tahun Pembelajaran pembelajaran kooperatif adalah model 2014/2015". pembelajaran kooperatif tipe tutor sebaya. Tutor sebaya merupakan pola pembelajaran dengan memberikan

\section{METODE}

Penelitian ini menggunakan dua tugas pada sekelompok siswa yang metode dalam mengumpulkan data telah tuntas terhadap bahan pelajaran agar memberi bantuan kepada siswa yang mengalami kesulitan dalam memahami bahan pelajaran yang dipelajarinya. Bantuan belajar oleh teman sebaya dapat menghilangkan kecanggungan. Model pembelajaran yang diterapkan oleh guru diasumsikan mendapatkan persepsi yang berbedabeda dari siswa. Peneliti beranggapan bahwa persepsi siswa terhadap penerapan model pembelajaran kooperatif tipe tutor sebaya memiliki hubungan yang signifikan dengan prestasi belajar siswa. Sesuai dengan latar belakang masalah di atas, maka peneliti bermaksud melakukan penelitian dengan judul: "Hubungan

Antara Persepsi Siswa Terhadap Penerapan Model Pembelajaran Kooperatif Tipe Tutor Sebaya dengan Prestasi Belajar Fisika pada Pokok Bahasan Getaran dan Gelombang Siswa Kelas VIII MTs yang disesuaikan dengan tujuan dan permasalahan penelitian. Teknik pengumpulan data yang dipergunakan adalah angket dan tes.

\section{Angket}

Angket merupakan teknik pengumpulan data yang dilakukan dengan cara memberi seperangkat pertanyaan atau pernyataan tertulis kepada responden untuk dijawabnya (Sugiyono, 2011: 199). Untuk memenuhi persyaratan sebagai alat ukur yang baik, maka angket yang digunakan harus memenuhi persyaratan valid dan reliabel.

- Uji Validitas Instrumen Angket Dalam pengujian validitas angket ini, akan menggunakan pendapat dari ahli (judgment experts).

- Uji Reliabilitas Instrumen Angket Perhitungan reliabilitas angket dalam penelitian ini akan menggunakan rumus Alpha.

$$
r_{11}=\left(\frac{k}{k-1}\right)\left(1-\frac{\sum \sigma_{b}^{2}}{\sigma_{t}^{2}}\right)
$$


Kriteria suatu instrumen dikatakan reliabel apabila koefisien reliabilitas $r_{11}>0,6$.

\section{Tes}

Tes adalah serentetan pertanyaan atau latihan serta alat lain yang digunakan untuk mengukur keterampilan, pengetahuan inteligensi, kemampuan atau bakat yang dimiliki oleh individu atau kelompok (Arikunto, 2010: 193). Instrumen tes ini harus memenuhi empat kriteria, yaitu validitas, reliabilitas, taraf kesukaran, dan daya pembeda.

- Uji Validitas Instrumen Tes

Pengujian validitas instrumen tes setiap butir soal dalam penelitian ini adalah menggunakan korelasi point biserial yang dinyatakan dalam persamaan berikut ini.

$$
r_{p b i s}=\frac{M_{p}-M_{t}}{S_{t}} \sqrt{\frac{p}{q}}
$$

Kriteria suatu instrumen dikatakan valid apabila uji $r_{\text {hitung }}>r_{\text {tabel }}$. Adapun $r_{\text {tabel }}$ dapat ditentukan dengan $r_{(\alpha ; n-2)}$ dengan taraf signifikan sebesar $5 \%$.

- Uji Reliabilitas Instrumen Tes Untuk mencari reliabilitas tes objektif, dicari dengan menggunakan rumus K-R 20 yaitu:

$$
r_{11}=\left(\frac{k}{k-1}\right)\left(\frac{v_{t}-\sum p q}{v_{t}}\right)
$$

Kriteria uji reliabilitas yang digunakan dalam penelitian ini adalah instrumen yang memiliki harga $r_{11}>0,6$.

- Uji Taraf Kesukaran Soal

Persamaan untuk mencari indeks kesukaran soal adalah sebagai berikut:

$$
P=\frac{B}{J S}
$$

Kriteria indeks kesukaran soal yang akan digunakan dalam penelitian ini adalah $25 \%$ soal sukar, 50\% soal sedang, dan $25 \%$ soal mudah.

- Uji Daya Pembeda Persamaan untuk menentukan daya pembeda adalah sebagai berikut:

$$
D P=\frac{B_{A}}{J_{A}}-\frac{B_{B}}{J_{B}}=P_{A}-P_{B}
$$

Nilai daya pembeda yang akan digunakan dalam penelitian ini adalah butir-butir soal yang memiliki indeks diskriminasi $D P \geq 0,20$.

Teknik Analisis Data

- Mean 
Rumus untuk menghitung mean adalah:

$$
\bar{X}=\left(\frac{\sum f_{i} x_{i}}{\sum f_{i}}\right)
$$

\section{- Median}

Rumus untuk mencari median adalah:

$$
M e=b+P\left(\frac{\frac{1}{2} n-F}{f}\right)
$$

\section{- Modus}

Rumus untuk mencari modus adalah:

$$
M o=b+P\left(\frac{b_{1}}{b_{1}+b_{2}}\right)
$$

\section{- Standar Deviasi}

Rumus untuk menghitung standar deviasi adalah:

$$
S D=\sqrt{\frac{N\left(\sum f_{i} x_{i}^{2}\right)-\left(\sum f_{i} x_{i}\right)^{2}}{N(N-1)}}
$$

- Kategori Tinggi, Sedang, dan

\section{Rendah}

Langkah menentukan kategori tinggi, sedang, rendah adalah sebagai berikut:

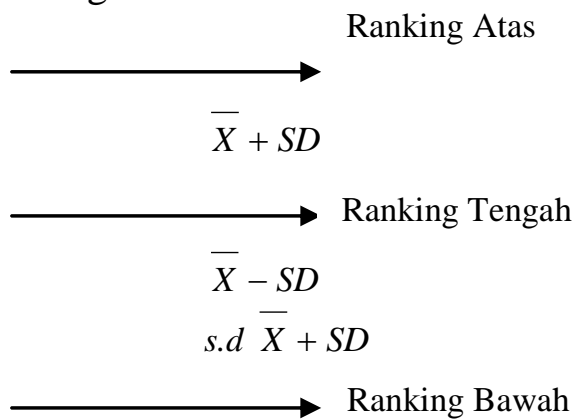

$$
\bar{X}-S D
$$

\section{Pengujian Hipotesis}

\section{- Uji Normalitas}

Rumus uji normalitas yang digunakan dalam penelitian ini adalah rumus Chi-kuadrat yaitu sebagai berikut:

$$
\chi^{2}=\sum \frac{\left(O_{i}-E_{i}\right)^{2}}{E_{i}}
$$

Kriteria pengujian nilai Chi kuadrat adalah sebagai berikut: Jika $\chi_{\text {hitung }}^{2} \leq \chi_{\text {tabel }}^{2}$, maka Ha diterima dan Ho ditolak (data berdistribusi normal). Jika $\chi$ $2_{\text {hitung }}>\chi_{\text {tabel }}^{2}$, maka Ho diterima dan $\mathrm{Ha}$ ditolak (data tidak berdistribusi normal).

\section{- Analisis Koefisien Korelasi}

Teknik atau metode analisis data untuk mengetahui koefisien korelasi digunakan rumus korelasi product moment sebagai berikut:

$$
r_{x y}=\frac{N \sum X Y-\left(\sum X\right)\left(\sum Y\right)}{\sqrt{\left.\left\{N \sum X^{2}-\left(\sum X\right)^{2}\right\} N \sum Y^{2}-\left(\sum Y\right)^{2}\right\}}}
$$

\section{- Analisis Koefisien Penentu}

Rumus untuk mencari koefisien penentu adalah: 


$$
K P=r^{2} \times 100 \%
$$

\section{- Analisis Regresi}

Persamaan regresi sederhana dapat dirumuskan sebagai berikut:

$$
\hat{Y}=a+b X
$$

Sedangkan rumus untuk mencari $a$ dan $b$ adalah:

$$
\begin{aligned}
& a=\frac{\sum Y-b \sum X}{N}=\bar{Y}-b \bar{X} \\
& b=\frac{N\left(\sum X Y\right)-\sum X \sum Y}{N \sum X^{2}-\left(\sum X\right)^{2}}
\end{aligned}
$$

- Uji Hipotesis

\section{Signifikansi Korelasi)}

Pengujian hipotesis dalam penelitian ini diuji dengan teknik uji $z$ yang dinyatakan dengan persamaan:

$$
z=\frac{r}{\frac{1}{\sqrt{n-1}}}
$$

Kriteria pengujian hipotesis dengan teknik uji z adalah Ho diterima dan Ha ditolak apabila $-z_{\alpha / 2} \leq z_{\text {hitung }} \leq z_{\alpha / 2}$ dan Ho ditolak dan Ha diterima apabila $z_{\text {hitung }}>z_{\alpha / 2}$ atau $z_{\text {hitung }}<-z_{\alpha / 2}$.

\section{HASIL DAN PEMBAHASAN}

\section{Hasil Penelitian}

Pada pengujian validitas instrumen angket, diperoleh 21 item pernyataan dengan kategori baik dan 4 item pernyataan dengan kategori cukup. Dari hasil tersebut, instrumen angket ini dapat digunakan dalam penelitian. Sedangkan hasil pengujian reliabilitas instrumen angket diperoleh nilai $r_{11}=0,82$. Harga $0,82>0,6$ sehingga instrumen tersebut dikatakan reliabel. Hal ini berarti instrumen angket tersebut dapat dipercaya dan tidak mengarahkan responden untuk memilih jawaban-jawaban tertentu.

Hasil pengujian validitas instrumen tes, dari 25 soal yang diujicobakan semua instrumen dinyatakan valid. Keseluruhan dari soal ini selanjutnya akan disaring kembali berdasarkan kriteria lainnya untuk dapat digunakan dalam penelitian ini. Hasil perhitungan reliabilitas diperoleh nilai $r_{11}=0,88$. Nilai ini dapat dikatakan reliabel $\left(r_{11}>0,6\right)$. Oleh karena itu, dapat disimpulkan instrumen ini layak untuk digunakan dalam penelitian ini. Pada perhitungan taraf kesukaran soal diperoleh 6 soal dengan kriteria mudah, 13 soal dengan kriteria sedang, dan 6 soal dengan kriteria sukar. Proporsi taraf kesukaran soal telah terpenuhi, sehingga instrumen ini dapat digunakan dalam 
Effendi - Hubungan Persepsi Siswa...

penelitian. Pada perhitungan daya seluruh soal tersebut dapat digunakan pembeda soal, diperoleh 1 soal dengan dalam penelitian.

kriteria baik sekali, 10 soal dengan Hasil pemusatan dan kriteria baik, 14 soal dengan kriteria penyebaran data skor angket persepsi cukup, dan tidak ada butir soal dengan dan nilai tes prestasi seperti tabel 1 kategori jelek dan drop sehingga berikut.

Tabel 1. Data skor Angket Persepsi dan Nilai Tes Prestasi

\begin{tabular}{|l|l|c|}
\hline \multicolumn{2}{|c|}{ Data } & Nilai \\
\hline \multirow{4}{*}{ Skor Angket } & Rata-rata (Mean, $\bar{X})$ & 85,27 \\
\cline { 2 - 3 } & Median (Median, Me) & 86,50 \\
\cline { 2 - 3 } & Modus (Mode, Mo) & 87,10 \\
\cline { 2 - 3 } & Standar Deviasi $($ Standar Deviation, $S D)$ & 11,06 \\
\hline \multirow{3}{*}{ Nilai Tes } & Rata-rata $($ Mean, $\bar{X})$ & 67,77 \\
\cline { 2 - 3 } & Median (Median, Me) & 63,38 \\
\cline { 2 - 3 } & Modus (Mode, Mo) & 67,90 \\
\hline & Standar Deviasi $($ Standar Deviation, $S D)$ & 12,42 \\
\hline
\end{tabular}

Adapun Hasil perhitungan uji normalitas adalah sebagai berikut.

Tabel 2. Hasil Perhitungan Uji Normalitas

\begin{tabular}{|c|l|c|c|l|}
\hline No. & \multicolumn{1}{|c|}{ Data } & $\begin{array}{c}\text { Nilai } \\
\chi^{2}{ }_{\text {hitung }}\end{array}$ & $\begin{array}{c}\text { Nilai } \\
\chi^{2}{ }_{\text {tabel }}\end{array}$ & \multicolumn{1}{c|}{ Keputusan } \\
\hline 1. & Skor Angket & 6,0011 & 7,815 & Data berdistribusi normal \\
\hline 2. & Nilai Tes Prestasi & 5,0822 & 7,815 & Data berdistribusi normal \\
\hline
\end{tabular}

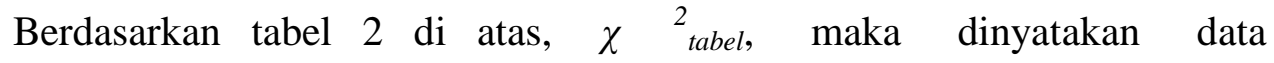
nilai $\chi^{2}{ }_{\text {tabel }}$ diambil berdasarkan nilai berdistribusi normal. Sebaliknya jika $\chi$ pada tabel konsultasi chi kuadrat pada ${ }^{2}$ hitung $>\chi^{2}$ tabel, maka data dinyatakan taraf signifikansi 5\% dengan $d k=k-3$ tidak berdistribusi normal. Pada tabel $=6-3=3$. Kolom keputusan dibuat tersebut terlihat bahwa nilai $\chi^{2}{ }_{\text {hitung }}$ berdasarkan pada ketentuan pengujian kedua data lebih kecil dari nilai $\chi^{2}$ tabel, hipotesis normalitas yaitu jika $\chi_{\text {hitung }}^{2} \leq$ 
sehingga dinyatakan bahwa kedua data berdistribusi normal.

Hasil perhitungan koefisien korelasi diperoleh nilai $r=0,89$. Jika diinterpretasikan dengan tabel nilai $r$, harga $r$ tersebut menunjukkan bahwa terdapat hubungan yang sangat tinggi antara variabel $X$ dengan variabel $Y$, dimana $0,80<r<1,00$.

Hasil perhitungan $K P$ diperoleh regresi menggunakan program SPSS nilai sebesar 79,21\%. Nilai $K P=16.0$ for Windows yang ditampilkan $79,21 \%$, artinya $79,21 \%$ persepsi siswa pada gambar berikut. terhadap penerapan model

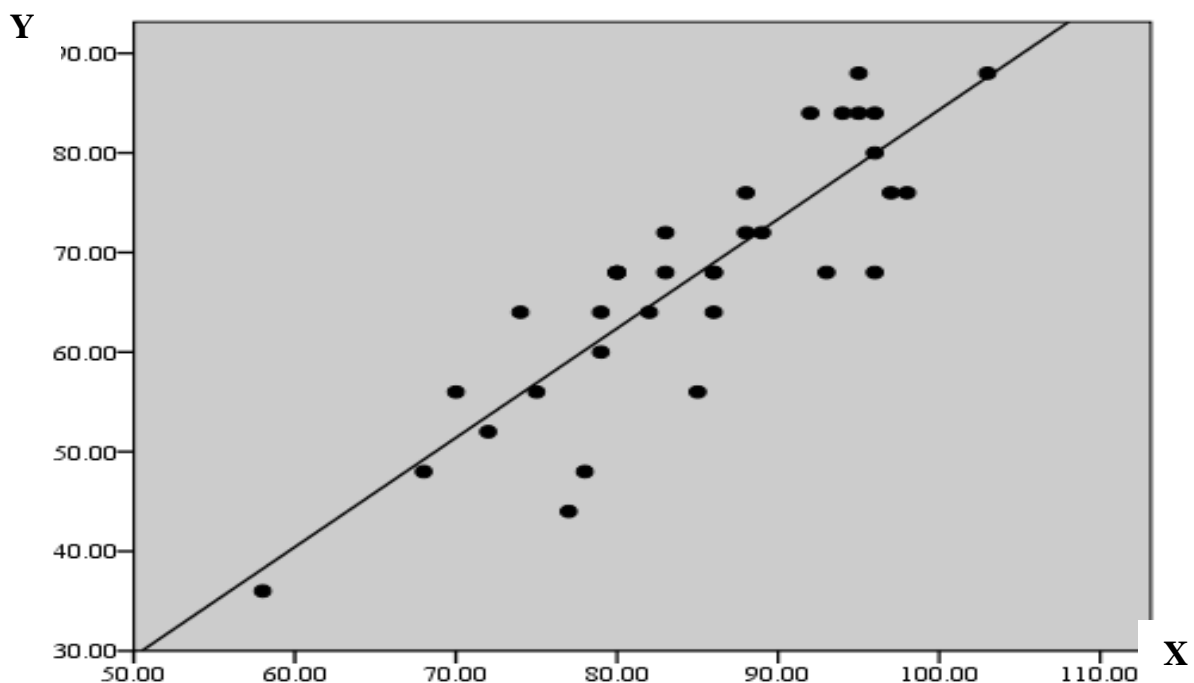

Gambar 1. Grafik Persamaan Regresi Linier Sederhana

Pada perhitungan pengujian penerimaan dan penolakan Ho pada hipotesis diperoleh $z_{\text {tabel }}=1,96$ atau - perhitungan hipotesis tersebut $z_{\text {tabel }}=-1,96$ pada taraf signifikansi 5\%, digambarkan dalam kurva berikut ini. sedangkan $z_{\text {hitung }}=5,1895$. Daerah pembelajaran kooperatif tipe tutor sebaya dapat mempengaruhi prestasi belajar, sedangkan 20,79\% ditentukan oleh faktor-faktor lain.

Hasil perhitungan analisis regresi diperoleh harga $a=-25,42$ dan harga $b=1,10$ sehingga persamaan regresinya adalah $\hat{Y}=1,10 X-25,42$. Untuk membuat grafik persamaan 16.0 for Windows yang ditampilkan 


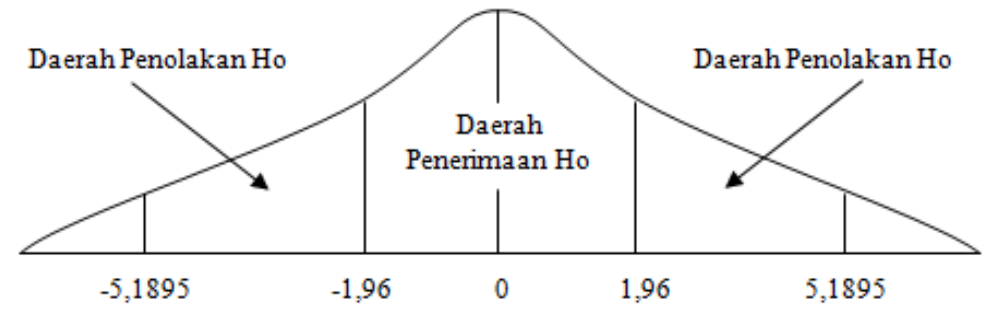

Gambar 2. Kurva Daerah Penerimaan Dan Penolakan Ho

Pada kurva tersebut terlihat penelitian menunjukkan bahwa bahwa zhitung berada di daerah persepsi siswa terhadap penerapan penolakan Ho. Artinya Ho ditolak dan model pembelajaran kooperatif tipe Ha diterima. Ini menunjukkan bahwa tutor sebaya tergolong sedang. Hal ini terdapat hubungan yang signifikan dapat dilihat dari rata-rata perolehan antara persepsi siswa terhadap skor angket persepsi sebesar 85,27 dari penerapan model pembelajaran skor maksimum 125. Jika dilihat dari kooperatif tipe tutor sebaya dengan kategorisasi persepsi siswa, terdapat prestasi belajar pada pokok bahasan perbedaan persepsi dari masing-masing getaran dan gelombang.

\section{Pembahasan}

Hasil uji hipotesis menunjukkan bahwa Ho ditolak dan Ha diterima. Hal ini berarti terdapat hubungan yang signifikan antara persepsi siswa siswa terdapat perbedaan persepsi meskipun kondisi dan objek yang dipersepsikan sama. Dari 35 siswa, terdapat $5(14,29 \%)$ siswa dengan persepsi tinggi, $25(71,42 \%)$ siswa terhadap penerapan model dengan persepsi sedang, dan 5 pembelajaran kooperatif tipe tutor (14,29\%) siswa dengan persepsi sebaya dengan prestasi belajar pada rendah. Perbedaan persepsi ini diduga pokok bahasan getaran dan gelombang. dari faktor-faktor seperti: perbedaan Untuk memperkuat temuan ini, pembelajaran kooperatif tipe tutor seperti yang telah diuraikan sebaya, perbedaan minat belajar fisika, sebelumnya telah dilakukan uji statistik dan perhatian mereka saat korelasi antara skor angket persepsi berlangsungnya proses pembelajaran. dengan prestasi belajar fisika. Hasil Hal ini seperti yang diungkapkan oleh 
Effendi - Hubungan Persepsi Siswa...

Sobur (2003: 452) yang Pearson diperoleh nilai $r$ sebesar $0,89$. mengemukakan faktor-faktor yang Harga $r$ tersebut menunjukkan bahwa mempengaruhi seleksi persepsi yaitu: terdapat hubungan yang sangat tinggi kebutuhuan psikologis, latar belakang, antara persepsi siswa terhadap pengalaman, kepribadian, sikap dan penerapan model pembelajaran kepercayaan umum, serta penerimaan kooperatif tipe tutor sebaya dengan diri.

Prestasi belajar fisika pada tersebut didapatkan nilai KP sebesar materi getaran dan gelombang $79,21 \%$. Nilai $K P=79,21 \%$, artinya tergolong sedang. Hal ini dapat dilihat $79,21 \%$ persepsi siswa terhadap dari nilai rata-rata yang diperoleh yaitu penerapan model pembelajaran 67,77 dari nilai maksimum 100. Jika kooperatif tipe tutor sebaya dapat dilihat dari kategorisasi prestasi belajar, mempengaruhi prestasi belajar, $6(17,14 \%)$ siswa termasuk ke dalam sedangkan $20,79 \%$ ditentukan oleh kategori tinggi, 24 (68,57\%), siswa faktor-faktor lain di luar persepsi.

kategori sedang, dan 5 (14,29\%) siswa Untuk memperkuat hal tersebut, kategori rendah. Perbedaan prestasi ini maka dilakukan analisis regresi dengan diduga dari perbedaan persepsi siswa persamaan $\hat{Y}=1,10 X-25,42$. Nilai $b$ terhadap penerapan model pada persamaan tersebut bernilai positif pembelajaran kooperatif tipe tutor sehingga garis persamaan regresi sebaya. Hal ini selaras dengan yang mengarah dari kiri naik ke kanan atas. diungkapkan oleh Djamarah (2010: Hal ini berarti semakin tinggi harga 33), secara garis besar faktor-faktor variabel $X$ (persepsi siswa terhadap yang dapat mempengaruhi prestasi penerapan model pembelajaran belajar adalah faktor psikologis seperti kooperatif tipe tutor sebaya), maka motivasi belajar, sikap, perasaan, akan semakin tinggi harga variabel $Y$ persepsi, minat, kondisi psikis, dan (prestasi belajar). Dan sebaliknya, kondisi akibat keadaan sosiokultur. semakin rendah harga variabel $X$

Berdasarkan hasil analisis (persepsi siswa terhadap penerapan koefisien korelasi yang menggunakan model pembelajaran kooperatif tipe rumus korelasi product moment Karl tutor sebaya), maka akan semakin 
Effendi - Hubungan Persepsi Siswa...

rendah harga variabel $Y$ (prestasi belajar).

Persepsi siswa yang baik tentang penerapan sebuah model pembelajaran mempunyai hubungan terhadap prestasi belajar. Namun demikian, dalam menerapkan sebuah model pembelajaran perlu dilakukan pembiasaan agar siswa terbiasa dan tidak kebingungan pada saat proses pembelajaran

\section{PENUTUP}

\section{Kesimpulan}

Berdasarkan hasil penelitian dan pembahasan, dapat disimpulkan bahwa terdapat hubungan yang signifikan antara persepsi siswa terhadap penerapan model pembelajaran kooperatif tipe tutor sebaya dengan prestasi belajar fisika pada pokok bahasan getaran dan gelombang siswa kelas VIII MTs Umbul Sari Buay Pemuka Bangsa Raja Tahun Pembelajaran 2014/2015.

\section{Saran}

Berdasarkan temuan-temuan selama penelitian, diberikan saran sebagai perbaikan di masa mendatang. Dari hasil penelitian memperlihatkan bahwa prestasi belajar siswa tinggi jika persepsi siswa terhadap penerapan model pembelajaran koperatif tipe tutor sebaya tinggi, dan sebaliknya prestasi belajar siswa rendah jika persepsi siswa terhadap penerapan model pembelajaran koperatif tipe tutor sebaya rendah. Sudah seharusnya sebelum melaksanakan pembelajaran, hendaknya memperhatikan aspek psikologis siswa seperti kesiapan untuk belajar, rasa ingin tahu, serta menggunakan model pembelajaran yang lebih variatif dan menarik. Hal ini diharapkan akan membuat persepsi siswa baik, sehingga terjadi peningkatan terhadap prestasi belajarnya.

\section{DAFTAR PUSTAKA}

Arikunto, Suharsimi. 2010. Prosedur Penelitian Suatu Pendekatan Praktik Edisi Revisi 2010. Jakarta: Rineka Cipta.

Djamarah, Syaiful Bahri, dan Aswin Zain. 2010. Strategi Belajar Mengajar. Jakarta: Rineka Cipta.

Hamalik, Oemar. 2005. Proses Belajar Mengajar. Jakarta: Bumi Aksara.

Sobur, Alex. 2003. Psikologi Umum. Bandung: Pustaka Setia.

Sugiyono. 2011. Metode Penelitian Pendidikan (Pendekatan Kuantitatif, Kualitatif, dan $R \& D)$. Bandung: Alfabeta. 